\title{
個体行動特性を考慮したハイブリッド型 群集津波避難シミュレーション
}

\author{
Hybrid Simulation for Tsunami Evacuation in Consideration of Individual Behaviors
}

\author{
加藤周平 $^{1} \cdot$ 下園武範 ${ }^{2} \cdot$ 岡安章夫 ${ }^{3}$
}

\section{Shuhei KATO, Takenori SHIMOZONO and Akio OKAYASU}

\begin{abstract}
A tsunami evacuation model is developed with a hybrid approach that combines two concepts of the potential method and the discrete element method. This model is accounting for a wide variety of individual behaviors as well as different types of interactions between evacuees. Conditions given in rather wide area such as evacuation directions are expressed by the potential model concept, and individual characteristics such as repulsion with other evacuees and attraction with members in the same group are considered by the discrete model. The model test is conducted in an actual bathing beach to confirm its performance. The model works for complicated behaviors of evacuees having different characteristics.
\end{abstract}

\section{1. はじめに}

四方を海に囲まれ, 大地震の多発地帯に位置する日本 は，常に津波災害の脅威にさらされている．津波の直撃 を受ける地域では, 迅速な避難が市民の生存のための必 須条件であり, 適切な避難指示, 誘導方法, 情報伝達方 法や避難施設の設置位置などの検討が急務となっている.

この様な背景の下で，避難計画を策定する上での有効 なツールとして, 津波避難シミュレーションが注目され, 近年各所で研究が行われている.より現実に近い避難状 況を再現するためには, 従来考慮されてきた個人の避難 能力等の要素に加えて, 避難開始時刻や避難場所・経路 に関する情報等の差異に起因する個人行動特性をいかに モデルに反映させるかが課題となっている．特に津波防 災に対する個人の意識や情報量は, 住民や外来客などに よって大きく異なることが示され（岡安ら，2007, 2009), 海水浴場等ではこうした属性の異なる個人が混在した状 況になっているため, 全体としての避難効率に大きく影 響すると考えられる.

本研究は, このような多様な個人特性を柔軟に組み込 むことが可能な, ポテンシャルモデルと個別要素法の考 え方の両方に基づいたハイブリッドモデルを構築するこ とを目的とした。

\section{2. 津波避難シミュレーション計算手法の構築}

本研究では, 既存のポテンシャルモデル (横山ら, 1993, 1995）と個別要素法（後藤ら，2004）の両手法を計算に 採用した. 地形・避難路・避難口・危険要素などの, 比

\begin{tabular}{|c|c|c|}
\hline 1 & 修 (工) & 元東京海洋大学大学院海洋科学技術研究科 \\
\hline 2 正会員 & 博 (工) & 東京海洋大学助教＼cjkstart海洋科学部 \\
\hline 3 正会員 & 工博 & 東京海洋大学教授 \\
\hline
\end{tabular}

較的広域な空間に影響を及ぼす要因についてはポテンシ ヤルモデルを, 要素間作用力（衝突回避力）などの避難 者間の相対位置による効果，壁面などの空間情報につい ては個別要素法の考え方に基づいた。個人行動特性につ いては, 個人に異なるポテンシャルマップを持たせる方 法（情報量の差異など）と個人に異なる行動特性（歩行 速度など）を与える方法を適宜使い分けることで柔軟に モデルに反映することが可能となる.

以下ではモデルを構成する各要素について詳しく説明 する.

（1）ポテンシャルモデル

本研究で取り扱ったポテンシャルモデルは, 横山ら （1993，1995）が提案したモデルを基本とした. 既存のポ テンシャルモデルでは, 各要素がグリッド上のみを運動 するが，ここでは各要素により自由度を持たせ，グリッ ド上だけではなく，自由に運動できるよう修正を行った。 ポテンシャルモデルを適用するには, 各要素の移動方向 を決める対象空間のポテンシャル分布（ポテンシャルマ ップ） $\Omega_{i}(\mathbf{X}, t)$ を作成する必要がある．作成にあたっては, まず避難口の幅方向の中心点 $j$ のポテンシャル值 $(=-1.0)$ を決め, 横山らの研究と同様にその他の点は次式で補間 した.

$$
\Omega_{i p}(t)=\sum_{j=1}^{n} c_{j} \exp \left[-\left(\frac{\Delta r_{i j p}}{d r_{i j}}\right)^{2}\right]
$$

$\Omega_{i p}(t)$ は, 避難者 $i$ に対する時刻 $t$ における点 $p$ のポテン シャル值, $n$ はポテンシャルを与えた点の数（避難口の数 など), $c_{j}$ は点 $j$ のポテンシャル值, $\Delta r_{i j p}$ は点 $j$ ポテンシャ ル值を求める点 $p$ までの距離である. また, $d r_{i j}$ は相関距 離と呼ばれ, 点 $j$ のポテンシャル值の距離方向の相関の程 度を決める係数である. 本研究では, ポテンシャルの勾 
配の緩急を調整するパラメーターとして用いた。この相 関距離を変えることで，たとえば避難口の幅の違いによ る避難行動への影響などをモデル化することができる.

避難者 $i$ に対するポテンシャル分布 $\Omega_{i}(\mathbf{X}, t)$ が定まった ときの移動方向ベクトル $\boldsymbol{u}_{i}(t)$ は, 図-1に示すように, 現 在位置 $\mathbf{X}_{0}=\left(x_{0}, y_{0}\right)$ の, 最近傍のグリッド点, $\mathbf{X}_{0}^{\prime}=\left(x_{0}^{\prime}, y_{0}^{\prime}\right)$ 上 のポテンシャル值と, その近接 8 点のグリッド $\mathbf{X}_{k}{ }_{k}(k=1,2$, $\cdots, 8)$ のポテンシャル值から次のように求める.

$$
\mathbf{u}_{i}(t)=\sum_{k} \mathbf{f}_{i k}\left(\mathbf{X}_{0}^{\prime}, t\right)+\alpha_{i} \mathbf{v}_{i}(t) \quad(k=1,2, \cdots, 8) \cdots(2)
$$

ここで,

$$
\begin{gathered}
\mathbf{f}_{i k}\left(\mathbf{X}_{\mathbf{0}}^{\prime}, t\right)=\left(\Omega_{i}\left(\mathbf{X}_{\mathbf{0}}^{\prime}, t\right)-\Omega_{i}\left(\mathbf{X}_{k}^{\prime}, t\right)\right) \cdot \frac{\left[\mathbf{X}_{k}^{\prime}-\mathbf{X}_{\mathbf{0}}^{\prime}\right]}{\left|\mathbf{X}_{k}^{\prime}-\mathbf{X}_{\mathbf{0}}^{\prime}\right|^{2}} . \\
(k=1,2, \cdots, 8)
\end{gathered}
$$

ただし，

$$
\begin{aligned}
& \mathbf{X}_{0}^{\prime}=\left(x_{0}^{\prime}, y_{0}^{\prime}\right), \mathbf{X}_{1}^{\prime}=\left(x_{0}^{\prime}+d_{x}, y_{0}^{\prime}\right) \\
& \mathbf{X}_{2}^{\prime}=\left(x_{0}^{\prime}+d_{x}, y_{0}^{\prime}+d_{y}\right), \mathbf{X}_{3}^{\prime}=\left(x_{0}^{\prime}, y_{0}^{\prime}+d_{y}\right) \\
& \mathbf{X}_{4}^{\prime}=\left(x_{0}^{\prime}-d_{x}, y_{0}^{\prime}+d_{y}\right), \mathbf{X}_{5}^{\prime}=\left(x_{0}^{\prime}-d_{y}, y_{0}^{\prime}\right) \\
& \mathbf{X}_{6}^{\prime}=\left(x_{0}^{\prime}-d_{x}, y_{0}^{\prime}-d_{y}\right), \mathbf{X}_{7}^{\prime}=\left(x_{0}^{\prime}, y_{0}^{\prime}-d_{y}\right) \\
& \mathbf{X}_{8}^{\prime}=\left(x_{0}^{\prime}+d_{x}, y_{0}^{\prime}-d_{y}\right)
\end{aligned}
$$

である。式（2）の第2項は，人間が進行方向を選択する 際に，直進方向を選びやすいという性質を反映するため のものであり係数 $\alpha_{i}$ によってその強度を調整する.ここ で, $v_{i}(t)$ は 1 ステップ前の移動方向を表す単位ベクトルで,

$$
\mathbf{v}_{i}(t)=\mathbf{u}_{i}(t-1) /\left|\mathbf{u}_{i}(t-1)\right|
$$

\section{として求める.}

\section{（2）接触回避力}

人間は，相互が物理的に接触する前に避けようとする 心理が働き，ある一定の距離を保とうとする。この衝突 を未然に防ごうと要素に力が働き始める距離は, 心理的 距離（仮想半径）と呼ばれる。このような個人の相互作 用については，個別要素法の考え方に基づいてモデルに 取り入れた。

ここでは, 要素間作用力は, 線形バネによる力のみを

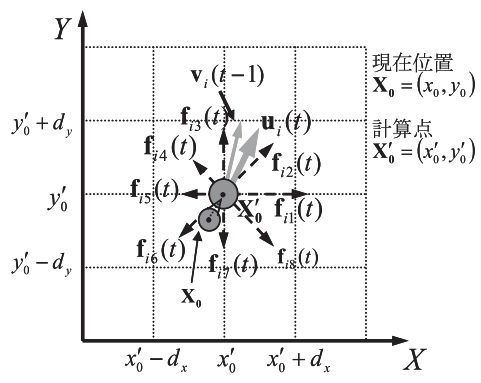

図-1 移動方向ベクトルの決定
考慮し, ダッシュポットによる力の減衰や, 要素の慣性 モーメントは考慮しなかった，要素 $i$ の仮想半径（心理 的距離) $r$ 内に存在する要素 $j$ から要素 $i$ には, バネ自然 長 $l$, バネ定数 $k$ のバネにより

$$
\mathbf{f}_{i j}=-k\left(l-\left|\mathbf{d}_{i j}\right|\right) \mathbf{d}_{i j} /\left|\mathbf{d}_{i j}\right|
$$

の反発力をうけるとする．ただし， $\mathbf{d}_{i j}$ は要素 $j$ から $i$ へ向 かうベクトルである.

一方，人間の視野を考慮すると，仮想半径内であって も, 要素は自身の正面方向にいる他要素から最も強く反 発力を受け, 逆に要素後方にいる他要素から反発力は弱 いと考えられる。そこで, 要素正面方向と, 要素 $i$ から 見た要素 $j$ の方向とのなす角を $\theta_{i j}$ とし, バネ定数 $k$ を次 式で与えた。

$$
k\left(\theta_{i j}\right)=k_{\max }\left(\alpha \cos \frac{\theta_{i j}}{2}+\beta\right)^{6}
$$

本研究では, 後藤らの研究を参考に $k_{\max }=600 \mathrm{~N} / \mathrm{m}$ とし, 係数 $\alpha, \beta$ はそれぞれ 0.7 および 0.3 とした. $k$ と $\theta_{i j}$ の関 係をグラフにすると図-2のようになる。したがって，要 素 $i$ に働く要素間作用力は, 式（6）および（7）より,

$$
\mathbf{f}_{i j}=-k(\theta)\left(l-\left|\mathbf{d}_{i j}\right|\right) \mathbf{d}_{i j} /\left|\mathbf{d}_{i j}\right|
$$

のように求まる。そして, 要素 $i$ に同時に複数から要素 間作用力が働くことを考慮し，

$$
\mathbf{F}_{\mathrm{sp} i}=\sum \mathbf{f}_{\mathrm{ij}}
$$

これを要素 $i$ に働く総要素間作用力とした.

(3) グループカ

緊急時の避難の際，家族や，仲間同士はグループ単位 で行動すると考えられる。このような行動は全体の避難 効率に大きく影響するため，グループ単位での行動が全 体の避難効率にも影響を与えるものと考えられる.そこ で，本研究では，同一グループの構成メンバー同士にか かる引力（グループカ）を導入した。すなわち，グルー

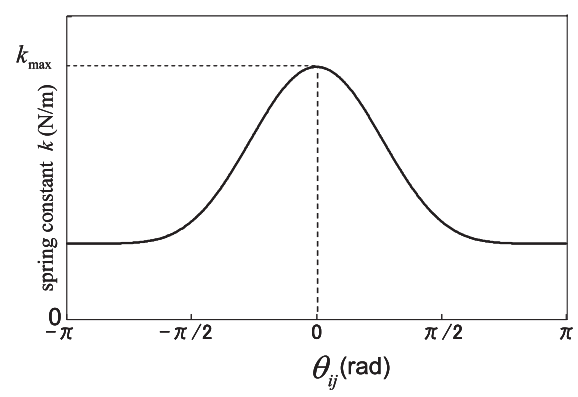

図-2 $\theta_{i j}$ とバネ定数 $k$ の関係 


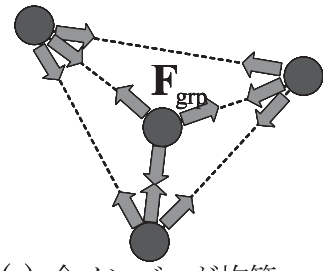

(a) 全メンバーが均等

図-3 グループカの作用

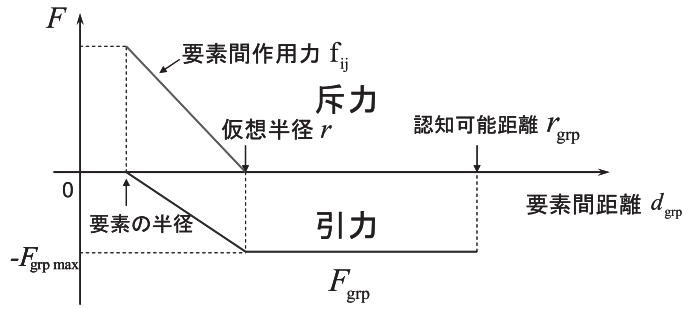

図-4 要素間距離と斥力・グループ力の設定

プカとは，メンバー同士が互いにはぐれない力，はぐれ た場合は集合する力である.

グループ力の働き方は，グループのメンバー構成によ って変わると考えられる．例えば，親子連れの場合， 「子供同士」よりも，「親と子」に働く引力のほうが強く なり，友人同士などの場合も，「リーダー対その他のメ ンバー」に働く引力が強くなると推測できる.よって本 研究ではグループの親・リーダーなどの中心となる人間 (要素) を1人と定め, グループのメンバー構成を単純化 し，図-3の2通りをグループカとして導入した。

また，人間の視野を考慮すれば，メンバーがお互いを 発見できる距離（認知可能距離 $r_{\mathrm{grp}}$ ) には限界がある. 図-4に本研究で仮定した同一グループメンバーの互いの 要素間距離とグループカとの関係を示す.

人間の視界を考慮すると, 認知可能距離 $r_{\mathrm{grp}}$ は, 自身 の周囲にいる人間の数 (仮想半径内の人数 $n_{\mathrm{d}}$, 混雑度) によって変化するはずである. 本研究では, ある避難者 が自身の仮想半径内に存在する他の避難者 8 人に 8 方向 から囲まれた状態で, 認知可能距離は最小值 $r_{\mathrm{grp} \text { min }}$ とな り, 自身の仮想半径内に他の避難者が 1 人増えるごとに, 最長距離 $r_{\mathrm{grp} \mathrm{max}}$ から $1 / 8$ ずつ短くなると仮定した。ここで は要素 $i$ 働く総グループ力は,

$$
\mathbf{F}_{\mathrm{grp} i}=\sum^{n_{\mathrm{gp}}-1} \mathbf{F}_{\mathrm{grp} i}^{\prime}
$$

のようになる．ここで， $n_{\mathrm{grp}}$ はグループメンバー数であ る. 図-5には, このグループ力により避難群集の中で, グループメンバーが集合する結果の一例を示している. 図中で $\mathrm{a}$ と bが互いに引き合い集合している様子が確認で きる。

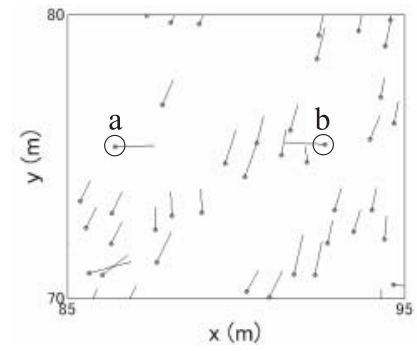

図-5 グループ効果を示す計算結果 (バーは移動ベクトルを表す)

\section{（4）他の避難者への追従}

避難の情報が少ない場合，他の避難者に追従する属性 を持つ避難者が存在すると考えられる.この避難者は周囲 に存在する全避難者の重心方向に移動すると考え, 重从係 数を用いたポテンシャルマップにより移動特性に加えた.

\section{（5）避難者の歩行速度}

本モデルでは, 各要素はポテンシャル以外の外的な要因 （障害物, 他の要素など）がない限り, 各要素の最大歩行 速度で運動するものとした. よって, 式 (2) で求まる $\mathbf{u}_{i}(t)$ の単位べクトル $\mathbf{u}_{i}(t)$ に要素 $i$ の最大歩行速さ $v_{\text {imax }}$ を乗じ,

$$
\mathbf{v}_{\mathrm{P}_{i}}(t)=v_{i_{\max }} \hat{\mathbf{u}}_{i}(t)
$$

をポテンシャル場の影響のみによる各要素の歩行速度と

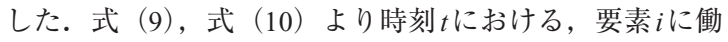
く力は,

$$
\mathbf{F}_{i}(t)=\mathbf{F}_{\mathrm{sp} i}(t)+\mathbf{F}_{\mathrm{gpp} i}(t)
$$

であるから, 時間ステップを $\Delta t$ とし, 要素 $i$ の体重（質 量）を $m_{i}$ とすると, 時刻 $t$ における要素 $i$ の速度は,

$$
\mathbf{v}_{i}(t)=\mathbf{v}_{\mathbf{P}_{i}}(t)+\frac{\mathbf{F}_{i}(t)}{m_{i}} \Delta t
$$

となる.

\section{（6）仮想粒子}

護岸, 壁, 障害物, など空間を遮る構造物は仮想粒子 の集まりで表現し, 衝突回避力によって避難者がそれを 超えて移動できないようにした．仮想粒子の概念を導入 することにより，ポテンシャルマップでは表現しきれな い細かく複雑な空間構造も表現することができ，大まか な空間構造を表現するポテンシャルマップとの役割分担 を可能にした。

\section{（7）各要素の微小ポテンシャル値}

本研究では, 各要素に微小な正のポテンシャル值 $(=0.002)$ を与えた。これにより, 人間が存在する位置のポテンシ ヤル值が相対的に高くなり, 各要素が人間の密度 (混雑) を考慮した移動方向ベクトルの決定が可能になった. 


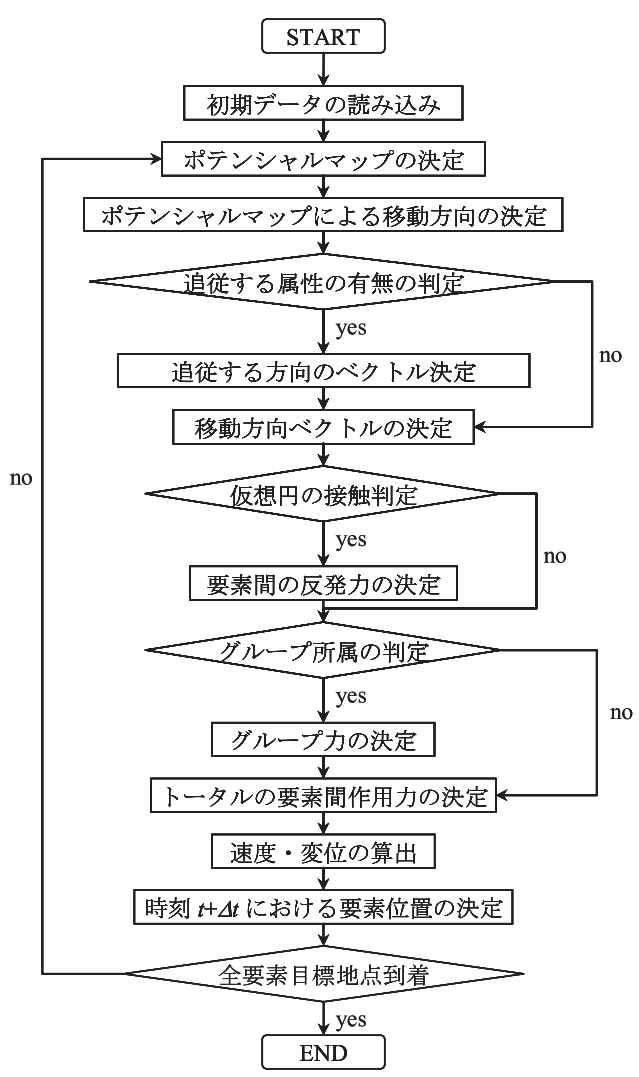

図-6 計算アルゴリズム

\section{(8) ポテンシャルマップのON/OFF}

ポテンシャルモデルは状況に応じて, 要素の全空間ま たは一部空間のポテンシャルマップのON/OFFを切り替え ることができる。例えば，津波警報発生の初期の段階に おいて，メンバー同士がはぐれているグループは避難を 開始する前に，グループが集合する行動をとる場合もあ ると考えられる。これは，避難出口などの情報が反映さ れているポテンシャルマップを無視する行動である。よ って，ポテンシャルマップの ON/OFFを動的に切り替える ことによってこのような行動を表現することができる。

以上で説明したモデルによる計算の流れを図-6に示す。

\section{3. 三浦海岸への適用}

ここでは本研究が開発したモデルの実海岸への適用例 を示す．対象としたのは神奈川県三浦市の三浦海岸であ る. 同海岸は三浦半島の南東部に位置し, 都心からのア クセスが良いことから，海水浴シーズンには毎年 50 万人 近くの人々が訪れている．普段は波穏やかで，海水浴に 適した海岸であるが，南関東大地震や東海地震発生時に は最大 $5 \mathrm{~m}$ 程度の津波の到達が予想されている（中央防 災会議，2003；神奈川県，2007）。

本研究では, 実際の海岸への避難シミュレーション適

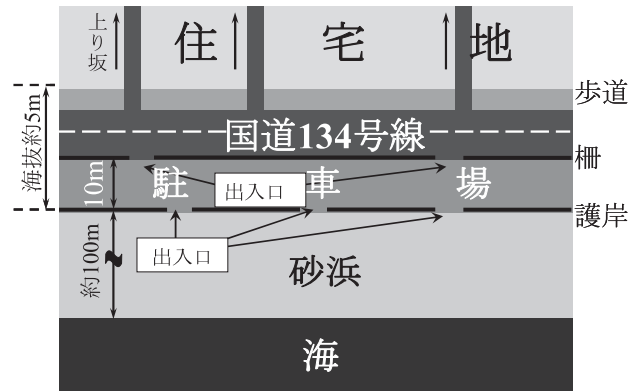

図-7 三浦海岸の空間構造

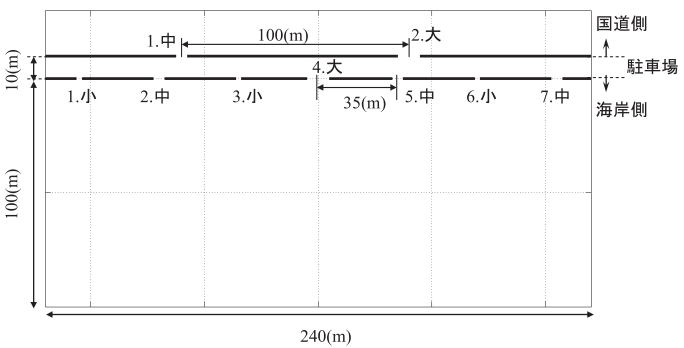

図-8 三浦海岸シミュレーションにおける避難口の配置

用にあたり，調査の利便性も考慮し，三浦海岸が比較的 単純，かつ，全国の海岸に多く見られる空間構造である ため選定した. 図-7に三浦海岸の空間的な構造を示す.

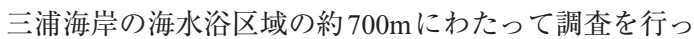
た結果，（i）海岸 $\rightarrow$ 駐車場出入口間隔：平均 $35 \mathrm{~m}$, (ii) 駐 車場 $\rightarrow$ 国道出入口間隔：平均 $100 \mathrm{~m}$ であった。駐車場から 国道への出口が少なく, 駐車場から国道側への避難が困 難となる可能性が大きいと考えられる．また，同出入口 には自動車等の進行防止のバーがある筒所が多数見られ， 迅速な避難をより困難にさせる可能性が考えられる，本 研究では国道を避難目標地点とし，海水浴場の一部，海 岸幅 $240 \mathrm{~m}$ を計算対象区域とした。さらに護岸・柵・避難 口などの調査に基づき, 避難口を大：10m，中： $5 \mathrm{~m}$ ，小： $2.5 \mathrm{~m}$ のように避難口を分類し，図-8のように設定した。そ して，避難口の分布・幅に従い図-9に示すような 2 種類の ポテンシャルマップを作成し，仮想粒子を護岸・柵の部 分に配置した。2種類のマップを作成したのは，利用者が 国道から駐車場へ入場した際に利用した出入口を主に認 識していると仮定したためで，各々のマップを全避難者 の半数ずつに与えた.

避難開始時刻 $(t=0)$ を津波警報発令時刻と定義し, 全避難者 1500 人, グループの構成人数を $2 \sim 5$ 人（各 75 グループ）とし，追従属性を持つ避難者（避難情報の少 ない避難者）の比率を変化させた場合についてシミュレ ーションを行った．各計算条件を表-1に示している.

図-10に $t=60$ sに打ける全体の避難の様子を，図-11に 追従する属性を有する避難者の割合と避難完了時間の関 係を示す．本計算ではポテンシャルマップを 2 通り与え 
たため，必ずしも最短距離の避難口に向かうわけではな いことや，避難者が国道側の避難口をどちらか1つしか 認識していない場合でも，無条件にその避難口へ移動す るのではなく，近くの避難口へ向かう行動が確認された (図-12)。また，離れ離れになったグループが集合する様 子や，他の避難者に追従する傾向も表現できた．定量的 には不確定要素が多々あるものの，こうした個人行動特 性が全体の避難効率に影響を及ぼすことが確認できた。 本モデルを用いれば，従来の避難シミュレーションでは 限界のあった，個人行動特性に多用な差異がある場合の， より現実的な避難行動を表現できるものと考えられる.
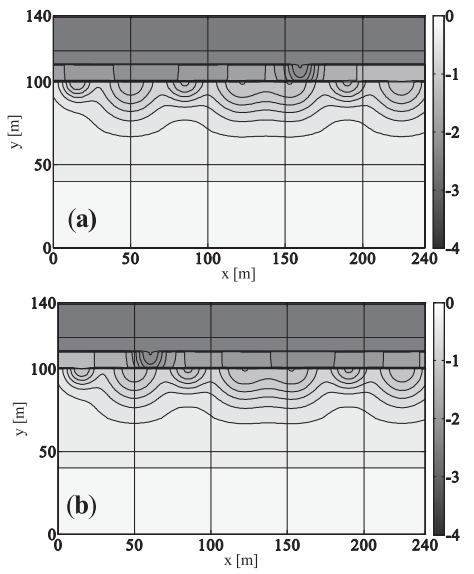

図-9 三浦海岸のポテンシャルマップ

表-1 シミュレーション各種条件

\begin{tabular}{l|c}
\hline 全避難者数 $(人)$ & 1500 \\
\hline 目標地点 & 国道 $($ 空間 3$)$ \\
\hline 津波警報発令時刻 $(\mathrm{s})$ & $t=0$ \\
\hline 避難開始時刻 $(\mathrm{s})$ & $t=0$ \\
\hline 歩行速度 $(\mathrm{m} / \mathrm{s})$ & 1.3 \\
\hline 計算時間ステップ $(\mathrm{s})$ & 0.1 \\
\hline グループメンバー数 $($ 人) & $2 \sim 5$ \\
\hline メンバー認知可能最大距離 $(\mathrm{m})$ & 30 \\
\hline 仮想粒子 & 各空間境界 \\
\hline ポテンシャル無視発動 $(\mathrm{s})$ & $t<60$ \\
\hline
\end{tabular}

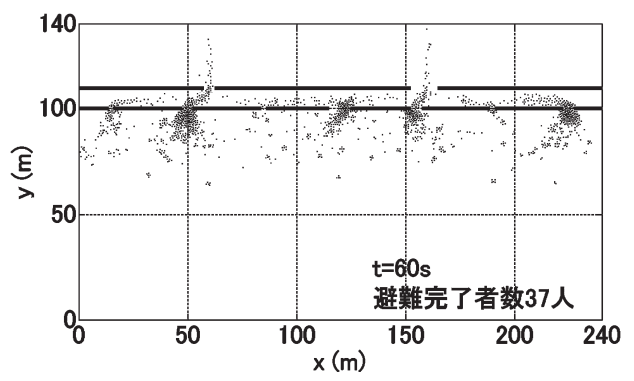

図-10 三浦海岸津波避難シミュレーション全体図の一例

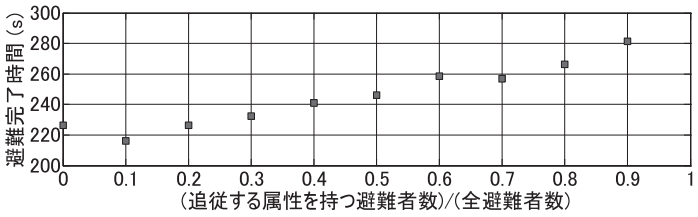

図-11 追従する属性を持つ避難者の比率と避難完了時間の関係

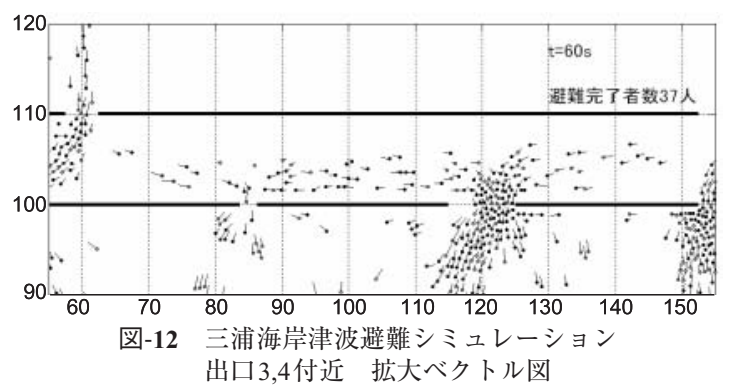

\section{4. まとめ}

避難者の行動の個人差，個々の属性，避難空間の設定 を柔軟に扱える新しい夕イプのハイブリッド型津波避難 シミュレーションツールを開発した。 三浦海岸をテスト ケースとしてシミュレーションを行い, 個々の機能がき ちんと作動し, 効果的な群集避難シミュレーションが行 えることを確認した。

今後は, 過去の避難シミュレーション, 群集行動, 群 集心理などの研究を参考に本研究で用いた各種パラメー ター值を同定し，本研究では実行に至らなかった定量的 な評価・検討方法を確立する必要がある.

\section{参 考 文 献}

岡安章夫 - 武若 聡 - 中野 晋・村上啓介・荒木進歩 - 森 信 人・青木伸一・今村文彦・越村俊一・佐藤㯖司（2007）： 津波防災に対する住民・海岸利用者の意識と対策立案者の 認識との相違に関する調査, 海岸工学論文集, 第 54 卷, pp. 1336-1340.

岡安章夫 - 村上啓介 - 森 信人 - 荒木進歩 - 川崎浩司 - 片山裕 之（2009）：津波防災における海岸利用者・住民の意識と 多椂性に関する調查，海洋開発論文集，第 25 巻，pp. 813817.

(神奈川県) 砂防海岸課: 神奈川県津波浸水予測図 (オンライン), http://www.pref.kanagawa.jp/osirase/sabo/kouwan/shinsui/shins ui.html.

後藤仁志・原田英治 - 久保有希 - 酒井哲郎 (2004) ：個別要素 法型群衆行動モデルによる津波時の避難シミュレーション, 海岸工学論文集，第51巻，pp. 1261-1265.

（内閣府）中央防災会議（2003）：東海地震に係る被害想定結 果について，東海地震対策専門調查会（オンライン）, http://www.bousai.go.jp/jishin/chubou/tou-tai/soutei2/kisha.pdf.

横山秀史・目黒公郎・片山恒雄（1993）：人間行動シミュレー ションによる地下街の安全性評価に関する研究, 生産研究, 45 卷 3 号, pp. 230-233.

横山秀史・目黒公郎・片山恒雄（1995）：避難行動解析へのポ テンシャルモデルの応用, 土木学会論文集 No.513/I-31, pp. 225-232 